\title{
ZIC1 Gene
}

National Cancer Institute

\section{Source}

National Cancer Institute. ZIC1 Gene. NCI Thesaurus. Code C75534.

This gene is involved in regulation of transcription, development and differentiation of cerebellar granule cells. 